\title{
ДОСЛІДЖЕННЯ ВПЛИВУ РАННЬОГО ХІРУРГІЧНОГО ЛІКУВАННЯ З ВИКОРИСТАННЯМ ГІДРОГЕЛЕВИХ РЕГЕНЕРАТИВНИХ ЗАСОБІВ ТА ГУБЧАСТИХ СОРБУЮЧИХ МАТЕРІАЛІВ НА ПОКАЗНИКИ МІКРОБНОГО ОБСІМЕНІННЯ PAH
}

Тернопільський державний медичний університет ім. І.Я. Горбачевського

\begin{abstract}
Досліджено динаміку змін показників мікробної контамінації експериментальних опікових ран у щурів при проведенні ранньої некректомії опікового струпу та подальшому закритті ран сучасними гідрогелевими пов'язками та сорбуючими губчастими засобами. Експериментально доведено, що комбіноване використання вторинного сорбуючого поліуретанового покриття та сітчастих гідрогелевих засобів на етапах раннього хірургічного лікування тварин значно знижує контамінацію патогенними мікроорганізмами, створює оптимальний мікроклімат для репаративної регенерації та оптимізує місцевий імунітет в опікових ранах.
\end{abstract}

Ключові слова: опіки, мікрофрлора, регенерація, імунітет.

На сьогодні методика лікування хворих з опіковою травмою принципово відрізняється від загальноприйнятих ще 10-15 років тому. Завдяки успіхам у вивченні патогенезу опікової хвороби та її ускладнень в сучасній комбустіології досягнуто значного прогресу. Широкі можливості відкрили дослідження мікробіологів й імунологів, спрямовані на виявлення механізмів взаємодії між організмом потерпілого від опіків та інсрекцією.

Важливим є визнання провідної ролі опікової рани в патогенезі опікової хвороби як основного джерела та місця проникнення інфрекції в організм обпеченого з наступним розвитком бактеріємії і бактерійної інтоксикації [1-3]. Не випадково ранова інфекція і токсемія бактерійного і гістіогенного походження набувають значення провідних патогенетичних ланок розвитку загальних і місцевих гемокоагуляційних і гемо-лімфоциркуляторних порушень у стадії септикотоксемії опікової хвороби [4-7].

Патогенна мікрофрлора на фоні інтоксикації організму продуктами розпаду термічно уражених тканин посилює деструктивні процеси в організмі на всіх рівнях його структурної організації [8-11]. При цьому нарос- тають явища порушення гомеостазу, які мали місце у більшості випадків, у тому числі на стадії токсемії і септикотоксемії.

Цілком закономірно, що при термічному ураженні порушується цілісність шкіри та слизових оболонок, що призводить до масивної мікробної інвазії, а рановий ексудат $є$ ідеальним середовищем для розвитку мікроорганізмів. Порушення мікроциркуляції призводять до утруднення надходження в рану фрагоцитів, антитіл, кисню, знижується хемотаксис і фрагоцитарна активність макрофагів і нейтрофілів рани, зменшується споживання нейтрофрільними лейкоцитами кисню, в організмі знижується вироблення гуморальних фракторів неспецифрічної резистентності. Значно страждає імунна система. Все це сприяє розвитку ранової інфекції і генералізації інфекційного процесу.

На сучасному етапі застосовується ряд ефективних методик у лікуванні хворих з опіками. Впровадження в клінічну практику ранньої хірургічної некректомії, 3 наступним закриттям ран регенеративними засобами, дозволяє покращити перебіг опікової хвороби [12-14], знизити прояви інтоксикаційного синдрому та запобігти розвитку інсрекційних ускладнень у хворих з критичними опіками [2, 4, 15]. При цьому адекватний підбір матеріалів для тимчасового закриття ранових поверхонь має важливе значення.

Останнім часом для місцевого лікування глибоких десектів шкіри знайшли широке використання засоби на гідрогелевій та гідроколоїдній основі [16-18]. Пов'язки цього типу забезпечують вологе середовище, абсорбують біологічні рідини і оберігають від накопичення виділень за рахунок випаровування води зовнішньою поверхнею пов'язки. Одним із напрямків підвищення лікувальної ефективності вказаних засобів $€$ розробка технологій та методик, спрямованих на підсилення їхньої сорбційної спроможності та покращення їх дренажних властивостей. 


\section{ОРИГІНАЛЬНІ ДОСЛІДЖЕННЯ}

\section{Матеріали і методи}

Експериментальне дослідження проведено на 192 безпорідних статевозрілих білих щурах, масою 250-300 г. Згідно з європейською конвенцією про гуманне поводження з лабораторними тваринами опік наносили під загальним ефрірним наркозом за методикою Regas F.C., Ehrlich H.P. (1992) [19]. Методика виконання експериментальної травми передбачала контактний опік III-IV ступеня звільненої від шерсті шкіри спини. Опік наносили мідною пластиною, яку попередньо розігрівали в кип'яченій воді при температурі 97-100 ${ }^{\circ} \mathrm{C}$. В подальшому щільно прикладали до шкірної поверхні піддослідної тварини протягом 20 с, при цьому площа опіку становила 10-15 \% поверхні тіла.

Згідно 3 європейською конвенцією про гуманне поводження з лабораторними тваринами опік наносили під загальним ефрірним наркозом за методикою Regas F.C., Ehrlich H.P. (1992) [1]. Дослідження проводились у відповідності до вимог сучасних етичних норм, що відображено у протоколі № 4 засідання комісії з біоетики дВНЗ “Тернопільський державний медичний університет імені І.Я. Горбачевського" від 09.04.2013 р.

Усіх піддослідних тварин розподілено на 3 групи. До складу контрольної групи включено 8 здорових тварин. До складу першої групи віднесено 24 тварини 3 опіковою травмою, лікування яких включало проведення некректомії на 6-у добу після травми; до другої групи увійшло 24 тварини, яким проводили раннє хірургічне лікування 3 використанням гідрогелевих монопов'язок; до третьої групи віднесено 24 тварини, яким проводили раннє хірургічне лікування з використанням сітчастих гідрогелевих пов'язок і поліуретанових адсорбентів.

Виділення та ідентифікацію аеробних мікроорганізмів здійснювали на живильних середовищах при культивуванні в термостаті при оптимальних температурних режимах.

Так, виділення та ідентифікацію різних видів стасрілококів проводили за морфологічними, тинкторіальними, культуральними (діаметр колоній, наявність пігменту, спроможність рости за аеробних і анаеробних умов, а також на агарі) та біохімічними властивостями [20], які вивчали 3 використанням комерційних мікробіологічних діагностикумів Мікро-Ла-Тест виробництва АТ «Лахема» (Чехія). Зазначені тест-системи містять висушені субстрати для ферментних реакцій, розташовані в лунках платівок для інокуляції. Субстрати розчиняються після додавання до інокуляту штаму, що проходить тестування. Протягом інокуляції перебігає біохімічна реакція, результат якої реєстрували візуально за зміною кольору індикатора або після внесення реактиву. Ідентифрікацію штаму, що тестували, проводили за допомогою порівняння отриманих результатів 3 аналогічними результатами тестів бактерійних штамів, наведених у таблицях для дисеренціації.
Ідентисрікацію стрептококів проводили за біологічними властивостями: продукцією гемолізинів, а також фрерментацією лактози, маніту, сахарози, арабінози, інсуліну [21].

Виділення та ідентифікацію псевдомонад (P. aeruginosa) здійснювали за допомогою середовища «Псевдомонас АПС-20».

Ідентифрікацію чистих культур ентеробактерій (ешерихій, ентеробактера, протеїв, клебсієл та ін.) проводили за методикою W. Ewing [22].

Для визначення наявності у бактерій каталази краплю перекису водню (3\%-ний розчин) наносили на предметне скло і вносили петлю культури, що тестувалась. За наявності каталази утворювалися пухирці кисню.

Ідентифрікацію виділених ізолятів Candida spp. проводили за допомогою тест-системи «Auxocolor» (BioRad, Франція).

Для ідентифікації аспорогенних облігатних анаеробних бактерій вивчали морфологічні, тинкторіальні, культуральні, біохімічні та біологічні властивості та користувалися рекомендаціями, розробленими у Харківському НДІ мікробіології та імунології ім. І.І. Мечникова.

\section{Результати досліджень та їх обговорення}

Мікробіологічне дослідження опікової рани щурів здійснювали на 7-у добу після травми, для цього використовували бактеріоскопічний (фрарбування за методом Грама з наступною імерсійною мікроскопією) та бактеріологічний методи [23].

У тварин контрольної серії через 7 днів після нанесення травми (на наступну добу після проведення некректомії) в рані переважали патогенні стафрілококи та стрептококи, кількість яких досягала $10^{7}$ КУО/мл змиву. Зазначені мікроорганізми характеризувались наявністю виражених патогенних властивостей, зокрема коазулазопозитивні стафрілококи та гемолітичні стрептококи. У значній кількості в рані також виявлені Bacillus cereus та Aspergillus sp., вміст яких досягав $10^{5} \mathrm{KУO/мл.} \mathrm{В} \mathrm{значно}$ меншій кількості-від $10^{2}$ до $10^{3}$ КУО/мл в рані виділяються S. epidermidis, S. saprophyticus, S. pyogenes, S. faecalis, E. coli ma P. aeruginosa (табл. 1). Значне навантаження рани мікроорганізмами свідчить про зниження локальної імунної реактивності, зокрема активності макрофрагів та гуморальних механізмів захисту. Кількість грибів роду Candida в рані незначна та не перевищує 80 КУО/мл змиву, що може свідчити про антагоністичні взаємодії грибів та сапрофрітних мікроорганізмів.

Проведення ранньої некректомії з використанням гідрогелевого моно-покриття призводить до зменшення мікробного навантаження на 7-у добу спостереження. Так, до $10^{5}$ КУО/мл зменшилась кількість стафрілококів та стрептококів. Проте, як і у попередній серії спостереження, значна їх кількість проявляла патогенні властивості. Разом 


\section{ОРИГІНАЛЬНІ ДОСЛІДЖЕННЯ}

з цим відбувається зменшення кількості Bacillus cereus та Aspergillus sp. до 103 КУО/мл змиву з рани. Епідермальний стасрілокок виділяється на рівні попередньої серії, проте наявність сапроорітних мікроорганізмів не є свідченням бактерійних ускладнень ранового процесу. Зростання активності місцевого захисту призводить до зникнення патогенних $S$. saprophyticus, S. pyogenes, S. faecalis та $P$. aeruginosa, a також зменшення кількості E. coli до менше ніж 90 КУО/ мл змиву з поверхні рани. Забруднення поверхні рани кишковою паличкою ймовірно носить фрекальний характер іу даному випадку він не досягає клінічно-вираженого значення. Кількість Candida sp. перевищує дані контрольної групи тварин, проте також знаходиться на рівні нижчому від порогового - $\leq 10^{2}$ КУО/мл.

Закриття поверхні рани сітчастими гідрогелевими засобами та поліуретановою губкою призводить до покращення мікробного пейзажу рани порівняно $з$ контр- олем та попердньою експериментальною групою. Так, відбувається значне зменшення кількості стрептококів - до $\leq 10^{2}$ КУО/мл при збереженні кількості стафрілококів на рівні попередньої серії, що може бути обумовлене антагоністичними взаємодіями між зазначеними таксономічними групами. Така картина характерна для збережених механізмів локального імунного захисту, який $€$ результатом створення оптимального мікрооточення в рані. При цьому відбувається значне зменшення кількості патогенних фрорм стафрілококів і стрептококів, що також $€$ показником активності імунних захисних механізмів в рані. Відбувається зникнення Aspergillus sp., які знаходились як у контролі, так і при застосуванні комбінованих гідрогелевих та сорбуючих засобів. S. saprophyticus, S. pyogenes, $S$. faecalis, E. coli та $P$. aeruginosa в рані не виявляються. Значно зменшується також кількість грибів, не перивищуючи 90 КУО/мл.

Таблиця 1

Кількісний та якісний склад мікрофрлори рани щурів на 7-у добу спостереження

\begin{tabular}{|l|c|c|c|}
\hline \multicolumn{1}{|c|}{ Мікроорганізм } & Контроль & $\begin{array}{c}\text { Гідрогелеві } \\
\text { монопокриття }\end{array}$ & $\begin{array}{c}\text { Гідрогелеві сітчасті покриття та } \\
\text { поліуретанові губки }\end{array}$ \\
\hline Staphylococcus sp. & $\leq 10^{6}$ & $\leq 10^{5}$ & $\leq 10^{5}$ \\
\hline Streptococcus sp. & $\leq 10^{7}$ & $\leq 10^{5}$ & $\leq 10^{2}$ \\
\hline Bacillus cereus & $\leq 10^{5}$ & $\leq 10^{3}$ & $\leq 10^{2}$ \\
\hline Aspergillus sp. & $\leq 10^{4}$ & $\leq 10^{3}$ & 0 \\
\hline S. epidermidis & $\leq 10^{2}$ & $\leq 10^{2}$ & 0 \\
\hline S. saprophyticus & $\leq 90$ & 0 & 0 \\
\hline S. pyogenes & $\leq 70$ & 0 & 0 \\
\hline E. coli & $\leq 10^{3}$ & $\leq 90$ & $\leq 90$ \\
\hline P. aeruginosa & $\leq 60$ & 0 & $\leq 10^{2}$ \\
\hline Candida sp. & $\leq 80$ & & 0 \\
\hline
\end{tabular}

На 14-у добу спостереження у тварин контрольної серії відмічається зменшення кількості в рані стафрілококів та стрептококів до рівня $10^{5}$ та $10^{6}$ КУО/мл змиву при збереженні їх патогенних властивостей. При цьому необхідно зазначити, що дана кількість мікроорганізмів перевищує поріг і може спричинити інфекційні ускладнення, включаючи сепсис. Bacillus cereus та Aspergillus sp. знаходяться на рівні $10^{5}$ та $10^{4}$ КУО/мл, що також $€$ значною кількістю. Через 14 днів зникають S. saprophyticus, $P$. aeruginosa та зменшується рівень $S$. saprophyticus до 90 КУО/мл, що свідчить про розгортання регенераційних процесів та зміцнення механізмів місцевого імунітету. Кількість кишкової палички складає $10^{2}$ КУО/мл, що свідчить про їх фекальне походження та недостатній імунний захист. Характерним є зростання кількості грибів роду Candida до $10^{2}$ КУО/мл, що може бути наслідком зменшення кількості бактерій на фроні зменшеного локального імунітету (табл. 2).
Проведення ранньої некректомії з використанням гідрогелевих монопокриттів призводить до значного зменшення мікробної контамінації поверхні опікової рани на 14-у добу. Так, в змивах виявляється значно менша кількість стафрілококів та стрептококів, кількість яких не перевищує $10^{4}$ КУО/мл. При цьому зазначені мікроорганізми майже не виявляють патогенних властивостей, що свідчить про значне підвищення локальних захисних механізмів. Кількість Bacillus cereus та Aspergillus становить $10^{3}$ та $10^{2}$ КУО/мл змиву, що $€$ значно менше як за показники контролю, так і за попередній термін спостереження, що свідчить про очищення рани та зміцнення захисних механізмів. Повністю зникають S. epidermidis, S. saprophyticus, S. pyogenes, $S$. faecalis, E. coli та $P$. aeruginosa та значно зменшується рівень Candida sp. до 80 КУО/мл. Кількість S. epidermidis, яка становить $10^{2}$ КУО/мл, є нормальним показником для поверхні шкіри щура. 


\section{ОРИГІНАЛЬНІ ДОСЛІДЖЕННЯ}

Таблиця 2

Кількісний та якісний склад мікрофрлори рани щурів на 14-у добу спостереження

\begin{tabular}{|l|c|c|c|}
\hline \multicolumn{1}{|c|}{ Мікроорганізм } & Контроль & $\begin{array}{c}\text { Гідрогелеві } \\
\text { монопокриття }\end{array}$ & $\begin{array}{c}\text { Гідрогелеві сітчасті покриття та } \\
\text { поліуретанові губки }\end{array}$ \\
\hline Staphylococcus sp. & $\leq 10^{5}$ & $\leq 10^{4}$ & $\leq 10^{3}$ \\
\hline Streptococcus sp. & $\leq 10^{6}$ & $\leq 10^{3}$ & $\leq 90$ \\
\hline Bacillus cereus & $\leq 10^{3}$ & $\leq 10^{3}$ & $\leq 10^{2}$ \\
\hline Aspergillus sp. & $\leq 10^{3}$ & $\leq 10^{2}$ & 0 \\
\hline S. epidermidis & $\leq 10^{2}$ & $\leq 10^{2}$ & 0 \\
\hline S. saprophyticus & $\leq 90$ & 0 & 0 \\
\hline S. pyogenes & 0 & 0 & 0 \\
\hline E. coli & $\leq 10^{2}$ & 0 & 0 \\
\hline P. aeruginosa & 0 & 0 & $\leq 80$ \\
\hline Candida sp. & $\leq 10^{2}$ & & 0 \\
\hline
\end{tabular}

Через 14 днів у тварин, яким для лікування рани використовували сітчасті гідрогелеві покриття та адсорбуючі поліуретанові засоби, відмічається майже повна нормалізація мікробного пейзажу, що є необхідною умовою нормального перебігу репаративних процесів. Так, на поверхні рани зберігаються незначна кількість стафрілококів без ознак патогенних властивостей та стрептококи, кількість яких не перевищує 90 КУО/мл. У такій же кількості зберігаються Bacillus cereus, проте вони не мають можливості ініціювати запальний процес. У кількості $10^{2}$ КУО/мл зберігається S. epidermidis, що також $€$ нормальним показником мікрофрлори шкіри щура.

В контрольній серії тварин на 21-у добу спостереження, незважаючи на майже повне закриття дефекту, встановлена значна мікробна контамінація поверхні рани. Порівняно з попереднім терміном спостереження відмічається зменшення кількості стафрілококів до $10^{3}$ КУО/мл, проте цей рівень перевищує поріг (табл. 3). Порівняно з попереднім терміном спостереження немає патогенних форм мікроорганізмів, що є сприятливим прогностичним критерієм. Рівень стрептококів та Bacillus cereus не перевищує поріг і становить $10^{2} \mathrm{KУO/мл,}$ також до 80 КУО/мл зменшується кількість Aspergillus sp. Патогенні мікроорганізми в рані не виявляються, окрім кишкової палички, кількість якої становить 70 КУО/мл. На рівні $10^{2}$ КУО/мл залишається кількість грибів роду Candida, що свідчить про зниження локальних захисних механізмів.

Таблиця 3

Кількісний та якісний склад мікрофрлори рани щурів на 21-у добу спостереження

\begin{tabular}{|l|c|c|c|}
\hline \multicolumn{1}{|c|}{ Мікроорганізм } & Контроль & $\begin{array}{c}\text { Гідрогелеві } \\
\text { монопокриття }\end{array}$ & $\begin{array}{c}\text { Гідрогелеві сітчасті покриття та } \\
\text { поліуретанові губки }\end{array}$ \\
\hline Staphylococcus sp. & $\leq 10^{3}$ & $\leq 10^{2}$ & 0 \\
\hline Streptococcus sp. & $\leq 10^{2}$ & 0 & 0 \\
\hline Bacillus cereus & $\leq 10^{2}$ & $\leq 90$ & 0 \\
\hline Aspergillus sp. & $\leq 80$ & 0 & $\leq 10^{3}$ \\
\hline S. epidermidis & $\leq 10^{2}$ & $\leq 10^{2}$ & 0 \\
\hline S. saprophyticus & 0 & 0 & 0 \\
\hline S. pyogenes & 0 & 0 & 0 \\
\hline E. coli & $\leq 70$ & 0 & 0 \\
\hline P. aeruginosa & 0 & 0 & $\leq 90$ \\
\hline Candida sp. & $\leq 10^{2}$ & & 0 \\
\hline
\end{tabular}

При застосуванні гідрогелевого монопокриття на 21-у добу спостереження відмічається майже повна нормалізація мікробного пейзажу поверхні шкіри тварин
- зникають стрептококи, кількість стафрілококів становить лише $10^{2}$ КУО/мл, при цьому патогенні форми відсутні. До 90 кУО/мл зменшується кількість Bacillus cereus та 


\section{ОРИГІНАЛЬНІ ДОСЛІДЖЕННЯ}

грибів роду Candida. Проте слід зауважити, що кількість останніх залишається на рівні попереднього терміну спостереження. Високим є рівень нормальної мікрофлори - кількість S. epidermidis становить $10^{2}$ КУО/мл змиву 3 поверхні рани.

Застосування сітчастого гідрогелевого покриття та поліуретанові губки для лікування опікової рани приводить до нормалізації її мікрофрлори на 21-й день спостереження. На поверхні шкіри виявляються поодинокі стафрілококи в кількості, що не перевищує 80 КУО/мл змиву та сапрофрітні S. epidermidis, кількість яких зростає до $10^{3}$ КУО/мл, що свідчить про відсутність пригнічуючої дії на ріст нормальної мікрофрлори з боку патогенної.

\section{Висновки}

1. Аналіз результатів бактеріологічних досліджень опікових ран в різних спостережуваних групах пацієнтів підтверджує високу лікувальну ефективність гідрогелевих засобів при проведенні хірургічної некректомії уражених термічним фрактором шкірних покривів. Стрімке зниження показників патогенної мікробної контамінації ран у 2-й і 3-й клінічних групах відбувалось в усі дні спостережень. Важливо відмітити, що місцеве використання ранових покриттів на гідрогелевій основі не пригнічує ріст сапрофрітних мікроорганізмів, що є свідченням позитивного впливу вищевказаних засобів на механізми локального імунітету.

2. Рання хірургічна ексцизія опікового струпа та закриття ран гідрогелевими пов'язками знижують контамінацію ран патогенними мікроорганізмами, створюють оптимальний мікроклімат для репаративної регенерації та оптимізують місцевий імунітет.

3. Комбіноване використання вторинного сорбуючого поліуретанового покриття та сітчастих гідрогелевих засобів сприяє активному дренажу виділень при надмірній ексудації, а відтак забезпечує адекватну санацію вогнищ інфікування уражених тканин.

\section{Література}

1. Толстов А.В. Ожоговый сепсис, диагностика, профилактика и лечение / А.В. Толстов, А.А. Филимонов, А.В. Колсанов // Актуальные вопросы военной медицины : 41-я итог. науч.-практ. конф. науч.-педагог. сост. Самарского воен.-мед. ин-та.: сб. статей. - Самара, 2008. - С. 81-84.

2. Толстов А.В. Новые подходы к диагностике, классификации и лечению генерализованной инфекции у тяжелообожженных / А.В. Толстов // Вест. Рос. Воен.-мед. акад. - 2007. - Т. 1, № 17, 4. 2. - C. 545-546.

3. A biological dressing versus 'conventional' treatment in patients with massive burns: a clinical trial / S.N. Hosseini, S.N. Mousavinasab, H. Rahmanpour, M. Fallahnezhad // Ulus Travma Acil Cerrahi Derg. 2009. - Vol. 15, N 2. - P. 135-140.

4. Коваленко О.М. Вплив раннього хірургічного лікування на перебіг і наслідки опікової хвороби у дорослих: автореф. дис. ... канд. мед. наук / О.М. Коваленко. - Київ, 2002. - 28 с.
5. Алексеев А.А. Актуальные вопросы организации и состояние медицинской помощи пострадавшим от ожогов в Российской Федерации / А.А. Алексеев, В.А. Лавров // ІІ съезд комбустиологов России, 2-5 июня 2008 г.: сб. науч. тр. - Москва, 2008. - С. 3-5.

6. Ожоги. Интенсивная терапия: учебное пособие для вузов / [И.П. Назаров, В.А. Мацкевич, Ж.Н. Колегова и др.]. - Красноярск: Феникс, 2007. - 415 с.

7. Комаров П.Д. Гемодинамика у шахтеров с тяжелой механической травмой / П.Д. Комаров, В.В. Мороз, Ю.А. Чурляев // Общая реаниматология. - 2007. - № 4. - С. 7-10.

8. Хушкадамов 3.К. Сосудисто-тканевые изменения внутренних органов при ожогах / 3.К. Хушкадамов, Х.М. Мирзоев // Таджикский институт последипломного образования: сб. тр. научн.-практ. конф. -2010 - С. $18-20$.

9. Применение энтеросорбции дляпросрилактики аутоиммунных процессов у больных с тяжелыми ожогами / Б.С. Шейман, О.И. Осадчая, Г.М. Боярская, Н.А. Волошина // Медицина неотложных состояний. - 2009. - № 3-4. - С. 36-39.

10. Ожоговая интоксикация: патогенез, клиника, принципы лечения / [Г.П. Козинец, С.В. Слесаренко, А.П. Радзиховский и др.]. - К.: МЕДпресс-инорорм, 2005. - 184 с.

11. Шерстобитов А.В. Состояние центральной гемодинамики и транспорта кислорода у шахтеров при тяжелой термической травме: дисс. ... канд. мед. наук / А.В. Шерстобитов. - Москва, 2009. - 135 c.

12. Система комплексного лікування опікової хвороби з метою профрілактики ранових ускладнень при хірургічному відновленні шкірного покриву / [О.В. Шаповал, Ю.І. Ісаєв, Т.Г. Григор'єва та ін.] // Наук. вісн. Ужгородського університету. Серія “Медицина”. 2006. - Вип. 27. - С. 73-79.

13. Нагайчук В.І. Раннє оперативне лікування хворих з поверхневими опіками / В.І. Нагайчук // Вісник Вінницького державного медичного університету. - 2006. - Т. 10, № 1. - С. 48-50.

14. Бігуняк В.В. Термічні ураження / В.В. Бігуняк, М.Ю. Повстяний. - Тернопіль: Укрмедкнига, 2004. - 196 с.

15. Шаповал О.В. Летальність хворих на опікову хворобу: фрункціональний аналіз передумов інфрузійного лікування / О.В. Шаповал // Актуальные проблемы медицины и биологии. - 2003. - № 1. - C. 370-375.

16. Hydrogen peroxide resolves neutrophilic inflammation in a model of antigen-induced arthritis in mice / F. Lopes, F.M. Coelho, V.V. Costa et al. // Arthritis Rheum. - 2011. - Vol. 10, N 2. - P. 169-172.

17. Opasanon S. Clinical effectiveness of alginate silver dressing in outpatient management of partial-thickness burns / S. Opasanon, P. Muangman, N. Namviriyachote // Int. Wound J. - 2010. - Vol. 7, N 6. - P. 467-471.

18. Park J.B. Healing of extraction socket grafted with deproteinized bovine bone and acellular dermal matrix: histomorphometric evaluation / J.B. Park // Implant. Dent. - 2010. - Vol. 19, N 4. - P. 307-313.

19. Regas F.C. Elucidating the vascular response to burns with a new rat model / F.C. Regas, H.P. Ehrlich // J. Trauma. - 1992. - Vol. 32, N 5. - P. 557-563.

20. Лабинская А.С. Микробиология с техникой микробиологических исследований / А.С. Лабинская. - М., 1972. - С. 185-192.

21. Экология микроорганизмов человека / [О.В. Бухарин, А.В. Валышев, Ф.Г. Гильмутдинова и др.]. - Екатеринбург: УРО $\mathrm{PAH}, 2006 .-480 \mathrm{c}$.

22. Медична мікробіологія, вірусологія, імунологія (підручник) // В.П. Широбоков, Н.О. Виноград та ін. - Вінниця: Нова книга, 2011. - 951 c.

23. Методы исследования в микробиологии: учеб.-метод. пособие / [Ж.Г. Шабан и др.]. - Минск: БГМУ, 2010. - 179 с. 


\section{STUDY OF EARLY SURGICAL TREATMENT WITH DRUGS AND HYDROGEL REGENERATIVE SORBENT SPONGE MATERIALS INDICATORS MICROBIAL CONTAMINATION SCIENCES}

A.O. Kovalchuk

SUMMARY. In this work the dynamics of changes in microbial contamination experimental burn wounds in rats during early necrosectomy burn scab wound clo- sure and subsequent modern hydrogel bandages and Sorbent sponged means. Experimentally proved that the combined use of recycled sorbent polyurethane coating and hydrogel cross-linked assets at the early stages of surgical treatment of animals reduces contamination by pathogenic microorganisms, creates an optimum microclimate for reparative regeneration and optimizes local immunity in burn wounds.

Key words: burns, microflora, regeneration, immunity.

Отримано 7.03.2015 p.

\title{
Л.Й. Ковальчук, А.В. Мокієнко, Л.П. Мельник \\ ХАРАКТЕРИСТИКА КОНТАМІНАЦІЇ ВОДИ ПОВЕРХНЕВИХ ВОДОЙМ УКРАЇНСЬКОГО ПРИДУНАВ'Я НАЙПРОСТІШИМИ І ГЕЛЬМІНТАМИ
}

\author{
Одеський національний медичний університет, Український НДІ медицини транспорту, \\ Одеський обласний лабораторний центр держсанепідемслужби України
}

Представлено результати санітарно-паразитологічних досліджень води поверхневих водойм Українського Придунав'я. Встановлено високий відсоток (60\%) контамінації води ооцистами Cryptosporidium spp. як ознаки наявності персистуючих джерел забруднення. Висловлено думку щодо антропогенності такого забруднення неочищеними стічними водами, носійства ооцист Cryptosporidium spp. населенням, необхідності верифрікації цих збудників при гастроентероколітах нез'ясованої етіології. Обірунтована необхідність оптимізації знезараження води та проведення систематичного санітарно-паразитологічного моніторингу води із застосуванням сучасних методів досліджень.

Ключові слова: поверхневі водойми, контамінація, найпростіші, гельмінти, Українське Придунав'я.

3 кожним роком проблема забруднення поверхневих водойм України збудниками паразитарних захворювань і гельмінтозів набуває все більшої актуальності. Наприклад, за даними В.С. Борисенко із співавт. (2009) [1], на території обслуговування СЕС Придніпровської залізниці за 2001-2007 рр. 20,6 \% проб води були позитивними.

Результати досліджень проб води поверхневих водойм 1-ої і 2-ої категорії на наявність ооцист криптоспоридій у м. Одесі та Одеській області за 2000-2004 рр. свідчать про виявлення цих біологічних контамінантів в 1 пробі з 7 і в 6369 проб відповідно [2].

Незважаючи на актуальність проблеми, яка обґрунтована у Керівництві ВООЗ [3], проаналізована у розділі монограсрії [4] та окремих публікаціях [5-8], санітарно-паразитологічних досліджень води, зокрема води поверхневих водойм, вкрай мало.

Українське Придунав'я, а це південні райони Одеської області (Ізмаїльський, Ренійський, Кілійський, Болградський, Татарбунарський), належить до депресивних регіонів України. Раніше конспективно зазначалось, що водні об'єкти даного регіону потерпають від надмірного антропогенного навантаження, що несприятливо позначається на якості питної води, яка споживається населенням [9, 10]. Однак слід зазначити, що одночасні санітарно-паразитологічні дослідження рівнів забруднення найпростішими і гельмінтами води 